\title{
Green Synthesis of Silver Nanoparticles using Colacasia Escullenta, Abutilon Indicum and Muntinga Calabura Vijayanand $\mathbf{S}^{*}$, Shahi P Ismail and Manaswi Manohar
}

\author{
Department of Life Sciences Kristu Jayanti College( Autonomous) Bengaluru \\ *Corresponding author vijayanand78bio@rediffmail.com
}

\begin{abstract}
The Development of well-grounded and eco-hospitable methods for the synthesis of nanoparticles is an important step in the field of nanotechnology. Silver nanoparticles are dominant because of their exceptional chemical, physical, and biological properties, and hence applications. In the last decade, countless efforts were made to develop green methods of synthesis to avoid the hazardous by products. The advantages of using plant and plant-derived materials for biosynthesis of metal nanoparticles have made a keen remark on researchers to investigate mechanisms of metal ions uptake and bio-reduction by plants, and to understand the possible mechanism of metal nanoparticle formation in plants. This review describes the methods of green synthesis for Ag-NPs and their countless applications. It also narrates the comparison of efficient synthesis methods via green routes over physical and chemical methods, which provide strong corroboration for the selection of suitable method for the synthesis of Ag-NPs. UV-Vis absorption spectroscopy was used to monitor the quantitative formation of silver nanoparticles. The characteristics of the obtained silver nanoparticles were studied using $X$-ray diffraction analysis $(\mathrm{XRD})$, energy-dispersive spectroscopy (EDX), and scanning electron microscopy (SEM).
\end{abstract}

Keywords: COLACASIA ESCULLENTA, ABUTILON INDICUM and MUNTINGA CALABURA, XRD- X-ray diffraction analysis, EDXenergy-dispersive spectroscopy, SEM- scanning electron microscopy

\section{Introduction}

Nature has devised various processes for the synthesis of nano and micro length scaled inorganic materials which have contributed in the development of relatively new and largely unexplored area of research based on the biosynthesis of the nanomaterials. Synthesis using bio-organisms is compatible with the green chemistry principles. "Green synthesis" of nanoparticles makes use of environmentally friendly, non-toxic and safe reagents. Nanoparticles synthesized using biological techniques or green technology have diverse natures, with greater stability and appropriate dimensions since they are synthesized using a onestep procedure. Nanoparticles can be synthesized using a variety of methods including chemical, physical, biological, and hybrid techniques. The development of green synthesis of Ag-NPs is advancing as a key branch of nanotechnology where the use of biological entities like plant extract or plant biomass, microorganisms for the generation of NPs could be an alternative to chemical and physical methods in an eco-friendly way. The advancement of green synthesis over physical and chemical methods are environment friendly, cost-effective, and easily scaled up for vast scale synthesis of NPs, while high-temperature, energy, pressure, and harmful chemicals are not required for green synthesis Hence, this review describes the green-inspired synthesis of $\mathrm{Ag}$ NPs that can provide advantage over the physical and chemical methods. The conventional methods for the production of NPs are expensive, toxic, and non-environment friendly. To overcome these problems, researchers have found the precise green routes, i.e., the naturally occurring sources and their products that can be used for the synthesis of NPs. Green synthesis can be categorized as: (a) utilization of microorganisms like fungi, yeasts (eukaryotes), bacteria, and actinomycetes (prokaryotes), (b) use of plants and plant extracts (c) use of templates like membranes, virus's DNA, and diatoms.

The objective of this study includes to screen the phytochemicals, to screen the pharmacological activity, to synthesise silver nanoparticles from plant extract and Characterization of silver nanoparticles.

\section{Methodology \\ Collection of Plant Samples}

The plants which were selected for the study was collected from all the different regions of Bengaluru. Mutingia calabura was collected from Chikkagubbi.Colacassia escueletta was collected from Ulsoor and Abutilon indicum was collected from Hoskote.

\section{Preparation of Plant Sample}

The collected plant sample was prepared by separating the plant parts namely -stem, tubers, flowers, fruits and leaves. The separated parts were shade dried and grinded until they appear as coarse powder. The powdered sample was stored for further analysis

\section{Preparation of Plant Extract}

The dried, powdered sample was subjected to soxhlation for preparation of plant extracts. The plant samples were extracted by using three different solvents namely ethanol, methanol and water. All the parts of the plant were subjected to soxhlation with all the three solvents separately by refluxing them for 6 cycles at 78.2,68 and 100 degree Celsius. The obtained extracts were collected and cooled at room temperature. Later was poured into a pre weighed beaker and was subjected to evaporation at $45^{\circ} \mathrm{C}$. The dried extracts were stored in air tight containers at 4-5 degree Celsius for further analysis.

\section{Phytochemical Analysis}


The dried extracts were subjected to premilinary phytochemical tests.

Phytochemical Analysis

\section{Test For Alkaloids}

\section{Wagner's test}

To $1 \mathrm{ml}$ of plant extract $1 \mathrm{ml}$ of wagners reagent was added. Brown/reddish precipitates visualises the presence of alkaloids.

\section{Test for Tannins}

\section{Ferric chloride test}

To $1 \mathrm{ml}$ of plant extract $1 \mathrm{ml}$ of $5 \%$ ferric chloride solution was added mixed well.Bluish black colour formation indicated the presence of tannins

\section{TEST FOR GLYCOSIDES}

\section{Salkowaskis test}

To $1 \mathrm{ml}$ of plant extract double the volume of chloroform was added and $1 \mathrm{ml}$ of concentrated sulphuric acid was added through the sides of test tube.Appearance of red green precipitate indicated the presence of glycosides

\section{TEST FOR STERIODS}

To $1 \mathrm{ml}$ of plant extract equal volume of chloroform was added and $1 \mathrm{ml}$ of concentrated sulphuric acid was added along the sides of test tube .Appearance of brown ring indicated the presence of steriods

\section{TEST FOR FLAVONOIDS}

\section{Lead acetate test}

To $1 \mathrm{ml}$ plant extract $1 \mathrm{ml}$ of $10 \%$ lead acetate solution was added. The mixture was mixed well .Appearance of yellow colour precipitate visualises the presence of flavonoids.

\section{TEST FOR TERPENOIDS}

\section{Salkowskis test}

To $1 \mathrm{ml}$ plant extract double the volume of chloroform was added and $1 \mathrm{ml}$ of concentrated sulphuric acid was added through the sides of test tube.Appearance of reddish brown precipitate indicated the presence of terpenoids.

\section{TEST FOR PROTEINS}

\section{Xanthoproetic test}

To $1 \mathrm{ml}$ plant extract 1-2 drops of concentrated nitric acid was added .Appearance of yellow colour indicates the presence of proteins.

\section{TEST FOR CARBOHYDRATES}

\section{Molisch test}

To $1 \mathrm{ml}$ plant extract $1 \mathrm{ml}$ of molisch reagent was added .Appearance of violet colour ring indicated the presence of carbohydrates.

\section{TEST FOR REDUCING SUGAR}

\section{Benedicts test}

To $1 \mathrm{ml}$ plant extract $1 \mathrm{ml}$ of benedicts reagent was added and was heated in boiling water bath for 15 minutes .Formation of orange red precipitate indicated the presence of reducing sugar.

\section{TEST FOR SAPONINS}

\section{Froth test}

To $1 \mathrm{ml}$ plant extract 3-4 drops of olive oil was added .Formation of froth indicated the presence of saponin

\section{TEST FOR DITERPENES}

Copper acetate test

To $1 \mathrm{ml}$ plant extract 10 drops of copper acetate solution was added .Appearance of green colour indicated the presence of diterpenes .

\section{GREEN SYNTHESIS OF SILVER NANOPARTICLES}

\section{$>$ PREPARATION OF PLANT EXTRACT}

Fresh,dried and powdered plant samples were weighed (30gm) accordingly. The weighed plant samples were disolved in distilled water and added to nine $500 \mathrm{ml}$ beaker .The samples were filtered using Whattman filter paper.The filtrate was made upto $200 \mathrm{ml}$.The filtrate from the first cycle was subjected for second filtration.

\section{Preparation of $1 \mathrm{M}$ silver nitrate solution(Stock solution)}

$16.987 \mathrm{gm}$ of silver nitrate was weighed and dissolved in $1000 \mathrm{ml}$ of double distilled water.

\section{$>$ SYNTHESIS OF PLANT EXTRACT}

$5 \mathrm{ml}$ of plant extract was added to all the tubes to prepare $10 \mathrm{ml}$ of $1 \mathrm{mM}, 2 \mathrm{mM}, 3 \mathrm{mM}, 4 \mathrm{mM}$ and $5 \mathrm{mM}$ silver nitrate solution .After addition of different concentration of silver nitrate solution the colour change from pale yellow to brown was noted down periodically. Formation of brown precipitate shows the formation of silver nanoparticles .

\begin{tabular}{|l|c|c|c|c|c|}
\hline SOLUTION & \multicolumn{5}{|c|}{ CONCENTRATION } \\
\hline & $1 \mathrm{mM}$ & $2 \mathrm{mM}$ & $3 \mathrm{mM}$ & $4 \mathrm{mM}$ & $5 \mathrm{mM}$ \\
\hline SILVER NITRATE & $4 \mathrm{ml}$ & $3 \mathrm{ml}$ & $2 \mathrm{ml}$ & $1 \mathrm{ml}$ & $5 \mathrm{ml}$ \\
\hline DOUBLE DISTILLED WATER & $1 \mathrm{ml}$ & $2 \mathrm{ml}$ & $3 \mathrm{ml}$ & $4 \mathrm{ml}$ & \\
\hline PLANT EXTRACT & $5 \mathrm{ml}$ & $5 \mathrm{ml}$ & $5 \mathrm{ml}$ & $5 \mathrm{ml}$ & $5 \mathrm{ml}$ \\
\hline
\end{tabular}

\section{CHARACTERIZATION OF SILVER NANOPARTICLES}

The green synthesised silver nanoparticles were characterized using several techniques. Absorption capacity of synthesised silver nanoparticles was checked using UV-Vis spectrophotometer. Energy dispersive X-ray analysis was performed to check the elemental / chemical composition of synthesised nanoparticles of silver. SEM analysis was performed for the detailed morphology of synthesised silver nanoparticles from different extracts.

\section{RESULT}

PHYTOCHEMICAL STUDIES 
Phytochemical study revealed the presence of different phytochemical constituents in ethanol, methanol and water aqueous extract of Colacassia stem, tuber and leaves followed by Abutilon leaf, stem and flower as well as Muntingia calabura leaf, stem and fruit. The result of phytochemical analysis is presented from table 1-9.

Colacasia plant sample confirms the presence of glycoside, steroid, flavonoids, terpenoids, saponin, diterpenes and carbohydrates in ethanol extract of tuber, stem and leaves extract, whereas in methanol extract flavonoid, saponin, diterpenes and carbohydrates are present in tuber, leaf and stem. In water extract all the phytochemicals are present in leaf and stem whereas steroids, proteins and reducing sugar are absent in tuber.

Qualitative analysis of phytochemicals of Muntigia calabura reveals the presence of alkaloids, tannins, glycosides, steroids, terpenoids, saponin in ethanol extract of leaf, stem and fruits. Alkaloids, tannins, glycoside, terpenoids, proteins, reducing sugar, saponins and carbohydrates are present in methanolic extract of Mutingia leaf, stem and fruit, whereas aqueous extract of Muntigia leaf, stem and fruit showed the presence of all the phytochemicals. Flavonoids of Muntigia leaf, stem and fruit in methanol, ethanol and water extracts found to be present in fairly good amount.

Qualitative analysis of phytochemicals of Abutilon indicum indicated the presence of alkaloids, tannins, flavonoids, steroids, proteins, reducing sugar saponins and carbohydrates in ethanolic extracts of Abutilon indicum leaf, stem and flowers. Alkaloids, tannins, flavonoids, terpenoids, Proteins, reducing sugar, saponins, diterpenes and carbohydrates are present in methanolic extract of Abutilon leaf, stem and flower. Alkaloids, tannins and flavonoids are found to be present in fairly good amount in aqueous extract of Abutilon flower, leaf and stem. From the various phytochemical tests conducted aqueous leaf extract of all the three-plant sample was found out to give presicse good results.

These phytochemicals are tend to be the most important non-nutritive part of the plant which has several pharmacological properties like flavonoids, saponins and terpenes have antiinflammatory and anticancer activity whereas terpenoids possess anticancer, antimicrobial, antifungal, antiviral, antihyperglycemic, analgesic, anti-inflammatory, and antiparasitic activity.

Due to all these biological activities, it is necessary to be screen the phytochemicals present in the plants which helps to classify our plants under medicinal properties. The results of Phytochemical analysis is depicted in the following (Table.1,2,3,4,5,6,7,8 \& 9).

Table 1: Phytochemical analysis of Colacassia escueletta leaf

\begin{tabular}{|l|l|l|l|}
\hline $\begin{array}{l}\text { Phytochemical } \\
\text { content }\end{array}$ & $\begin{array}{l}\text { Ethanolic } \\
\text { extract }\end{array}$ & $\begin{array}{l}\text { Methanolic } \\
\text { extract }\end{array}$ & $\begin{array}{l}\text { Aqueous } \\
\text { extract }\end{array}$ \\
\hline Alkaloids & + & - & ++ \\
\hline Tannins & + & + & ++ \\
\hline Glycosides & + & + & ++ \\
\hline Steroids & + & + & + \\
\hline Flavonoids & + & ++ & + \\
\hline Terpenoids & + & + & ++ \\
\hline Proteins & + & + & ++ \\
\hline Reducing sugar & + & + & + \\
\hline Saponins & + & + & ++ \\
\hline Diterpenes & + & + & ++ \\
\hline Carbohydrates & + & ++ & ++ \\
\hline
\end{tabular}

Absence (-), Presence (+), Fairly good amount (++)
Table 2: Phytochemical analysis of Colacssia esculetta stem

\begin{tabular}{|l|l|l|l|}
\hline $\begin{array}{l}\text { Phytochemical } \\
\text { content }\end{array}$ & $\begin{array}{l}\text { Ethanolic } \\
\text { extract }\end{array}$ & $\begin{array}{l}\text { Methanolic } \\
\text { extract }\end{array}$ & $\begin{array}{l}\text { Aqueous } \\
\text { extract }\end{array}$ \\
\hline Alkaloids & ++ & - & ++ \\
\hline Tannins & + & + & ++ \\
\hline Glycosides & + & + & ++ \\
\hline Steroids & + & - & ++ \\
\hline Flavonoids & + & + & ++ \\
\hline Terpenoids & + & + & + \\
\hline Proteins & + & + & + \\
\hline Reducing sugar & - & + & + \\
\hline Saponins & + & + & + \\
\hline Diterpenes & + & + & + \\
\hline Carbohydrates & + & + & ++ \\
\hline
\end{tabular}

Absence (-), Presence (+), Fairly good amount (++)

Table 3: Phytochemical analysis of Colacassia esculetta tuber

\begin{tabular}{|l|l|l|l|}
\hline $\begin{array}{l}\text { Phytochemical } \\
\text { content }\end{array}$ & $\begin{array}{l}\text { Ethanolic } \\
\text { extract }\end{array}$ & $\begin{array}{l}\text { Methanolic } \\
\text { extract }\end{array}$ & $\begin{array}{l}\text { Aqueous } \\
\text { extract }\end{array}$ \\
\hline Alkaloids & + & + & ++ \\
\hline Tannins & - & + & + \\
\hline Glycosides & + & - & + \\
\hline Steroids & + & - & - \\
\hline Flavonoids & + & + & ++ \\
\hline Terpenoids & + & - & ++ \\
\hline Proteins & - & - & - \\
\hline Reducing sugar & - & - & - \\
\hline Saponin & + & + & ++ \\
\hline Diterpenes & + & + & + \\
\hline Carbohydrates & + & + & + \\
\hline
\end{tabular}

Absence (-), Presence (+), Fairly good amount (++)

Table 4: Phytochemical analysis of Mutingia calabura leaf

\begin{tabular}{|l|l|l|l|}
\hline $\begin{array}{l}\text { Phytochemical } \\
\text { content }\end{array}$ & $\begin{array}{l}\text { Ethanolic } \\
\text { extract }\end{array}$ & $\begin{array}{l}\text { Methanolic } \\
\text { extract }\end{array}$ & $\begin{array}{l}\text { Aqueous } \\
\text { extract }\end{array}$ \\
\hline Alkaloids & ++ & + & ++ \\
\hline Tannins & + & ++ & ++ \\
\hline Glycosides & + & + & + \\
\hline Steroids & + & - & + \\
\hline Flavonoids & ++ & ++ & ++ \\
\hline Terpenoids & + & + & + \\
\hline Proteins & - & + & ++ \\
\hline Reducing sugar & + & + & ++ \\
\hline Saponins & + & + & + \\
\hline Diterpenes & + & + & + \\
\hline Carbohydrates & + & ++ & ++ \\
\hline
\end{tabular}

Absence (-), Presence (+), Fairly good amount (++)

Table 5: Phytochemical analysis of Mutingia calabura stem

\begin{tabular}{|l|l|l|l|}
\hline $\begin{array}{l}\text { Phytochemical } \\
\text { content }\end{array}$ & $\begin{array}{l}\text { Etanolic } \\
\text { extract }\end{array}$ & $\begin{array}{l}\text { Methanolic } \\
\text { extract }\end{array}$ & $\begin{array}{l}\text { Aqueous } \\
\text { extract }\end{array}$ \\
\hline Alkaloids & + & + & ++ \\
\hline Tannins & + & + & ++ \\
\hline Glycosides & + & + & ++ \\
\hline Steroids & + & - & + \\
\hline Flavonoids & ++ & ++ & ++ \\
\hline Terpenoids & + & + & + \\
\hline Proteins & + & + & ++ \\
\hline Reducing sugar & - & + & ++ \\
\hline Saponins & + & + & + \\
\hline Diterpenes & - & - & + \\
\hline Carbohydrates & + & + & ++ \\
\hline
\end{tabular}

Absence (-), Presence (+), Fairly good amount (++) 
Table 6: Phytochemical analysis of Mutingia calabura fruit

\begin{tabular}{|l|l|l|l|}
\hline $\begin{array}{l}\text { Phytochemical } \\
\text { content }\end{array}$ & $\begin{array}{l}\text { Ethanolic } \\
\text { extract }\end{array}$ & $\begin{array}{l}\text { Methanolic } \\
\text { extract }\end{array}$ & $\begin{array}{l}\text { Aqueous } \\
\text { extract }\end{array}$ \\
\hline Alkaloids & ++ & + & ++ \\
\hline Tannins & + & + & ++ \\
\hline Glycosides & + & + & + \\
\hline Steroids & + & - & + \\
\hline Flavonoids & ++ & ++ & ++ \\
\hline Terpenoids & + & + & + \\
\hline Proteins & + & + & + \\
\hline Reducing sugar & + & + & + \\
\hline Saponins & + & + & ++ \\
\hline Diterpenes & - & + & ++ \\
\hline Carbohydrates & - & + & ++ \\
\hline
\end{tabular}

Absence (-), Presence (+), Fairly good amount (++)

Table 7: Phytochemical analysis of Abutilon indicum leaf

\begin{tabular}{|l|l|l|l|}
\hline $\begin{array}{l}\text { Phytochemical } \\
\text { content }\end{array}$ & $\begin{array}{l}\text { Ethanolic } \\
\text { extract }\end{array}$ & $\begin{array}{l}\text { Methanolic } \\
\text { extract }\end{array}$ & $\begin{array}{l}\text { Aqueous } \\
\text { extract }\end{array}$ \\
\hline Alkaloids & + & ++ & ++ \\
\hline Tannins & + & + & ++ \\
\hline Glycosides & + & + & ++ \\
\hline Steroids & + & + & ++ \\
\hline Flavonoids & ++ & ++ & ++ \\
\hline Terpenoids & + & + & + \\
\hline Protewins & ++ & + & ++ \\
\hline Reducing sugar & ++ & + & ++ \\
\hline Saponins & + & + & ++ \\
\hline Diterpenes & + & + & ++ \\
\hline Carbohydrates & ++ & + & ++ \\
\hline
\end{tabular}

Absence (-), Presence (+), Fairly good amount (++)

Table 8: Phytochemical analysis of Abutilon indicum stem

\begin{tabular}{|l|l|l|l|}
\hline $\begin{array}{l}\text { Phytochemical } \\
\text { content }\end{array}$ & $\begin{array}{l}\text { Ethanolic } \\
\text { extract }\end{array}$ & $\begin{array}{l}\text { Methanolic } \\
\text { extract }\end{array}$ & $\begin{array}{l}\text { Aqueous } \\
\text { extract }\end{array}$ \\
\hline Alkaloids & + & + & ++ \\
\hline Tannins & + & + & ++ \\
\hline Glycosides & + & + & ++ \\
\hline Steroids & + & - & ++ \\
\hline Flavonoids & ++ & + & ++ \\
\hline Terpenoids & + & + & + \\
\hline Proteins & ++ & + & + \\
\hline Reducing sugar & + & ++ & ++ \\
\hline Saponins & ++ & + & + \\
\hline Diterpenes & + & + & + \\
\hline Carbohydrates & ++ & ++ & ++ \\
\hline
\end{tabular}

Absence (-), Presence (+), Fairly good amount (++)

Table 9: Phytochemical analysis of Abutilon indicum flower

\begin{tabular}{|l|l|l|l|}
\hline $\begin{array}{l}\text { Phytochemical } \\
\text { content }\end{array}$ & $\begin{array}{l}\text { Ethanolic } \\
\text { extract }\end{array}$ & $\begin{array}{l}\text { Methanolic } \\
\text { extract }\end{array}$ & $\begin{array}{l}\text { A q u e o u s } \\
\text { extract }\end{array}$ \\
\hline Alkaloids & + & + & ++ \\
\hline Tannins & + & + & ++ \\
\hline Glycosides & - & - & + \\
\hline Steroids & + & + & ++ \\
\hline Flavonoids & ++ & + & ++ \\
\hline Terpenoids & - & + & ++ \\
\hline Proteins & + & + & ++ \\
\hline Reducing sugar & + & + & ++ \\
\hline Saponins & + & + & + \\
\hline Diterpenes & - & + & + \\
\hline Carbohydrates & + & + & ++ \\
\hline
\end{tabular}

Absence (-), Presence (+), Fairly good amount (++)

\section{SYNTHESIS OF SILVER NANOPARTICLES}

The dried powdered plant samples were filtered with distilled water using Whattman filter paper with which different concentrations of silver nitrate solutions were prepared inorder to yield different concentrations of silver nanoparticles.The colour change from pale yellow to brown was noted down .Appearance of brown colour indicated the presence of silver nanoparticles .Abutilon leaf of $4 \mathrm{~mm}$ solution showed the colour change in 10 min as well as Colacassia leaf of $2 \mathrm{~mm}$ solution colour change took place in $10 \mathrm{~min}$. These two different sample of different concentration solutions showed the presence of silver nanoparticles. The synthesised silver nanoparticles were den subjected to further analysis for characterization

Figure.1-Green synthesis of Nanoparticle

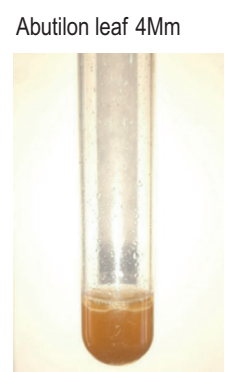

Colacassia leaf $2 \mathrm{~mm}$

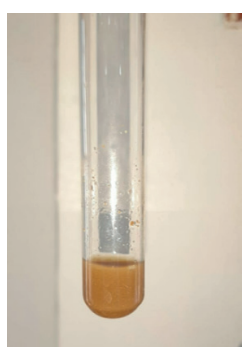

Figure.1-Green synthesis of Nanoparticle

\section{NANOPARTICLES ANALYSIS USING UV-VISIBLE SPECTROPHOTOMETER}

Synthesised silver nanoparticles were subjected for UVVis spectrophotometer at 250-700 nm, where all the different concentrations of synthesised silver nanoparticles were measured for the O.D. Namely Abutilon leaf of $4 \mathrm{mM}$ and Colacasia leaf of $2 \mathrm{Mm}$ showed the maximum absorption capacity Abutilon leaf of $4 \mathrm{mM}$ showed the maximum absorption peak at 412.- 813nm.On the other hand Colacasia leaf of $2 \mathrm{mM}$ showed the maximum absorption peak at $420 \mathrm{~nm}$ (Figure.2)

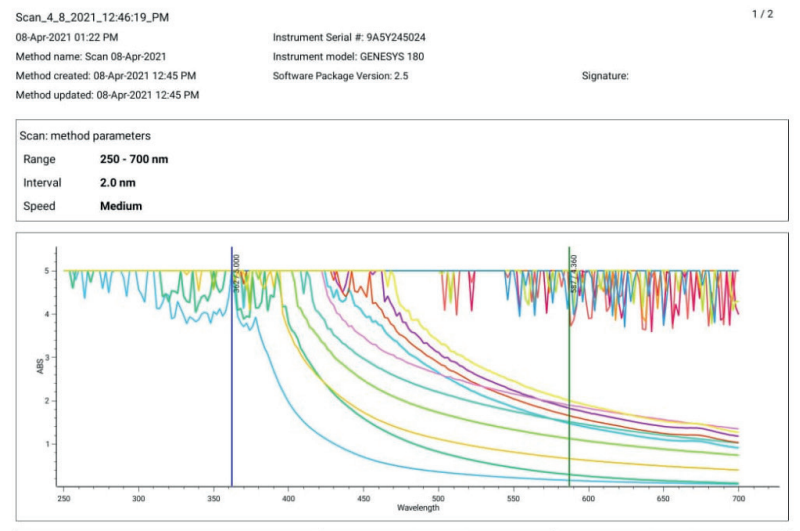




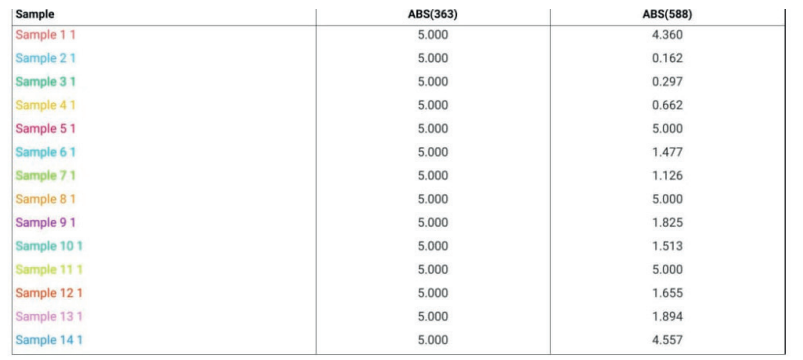

Figure .2 UV-Absorption spectrum analysis of Nanoparticles

\section{SEM-ANALYSIS}

The two concentrations of silver nanoparticles which were subjected to UV-Vis was further subjected to SEM analysis. (Figure.3\& 4 )

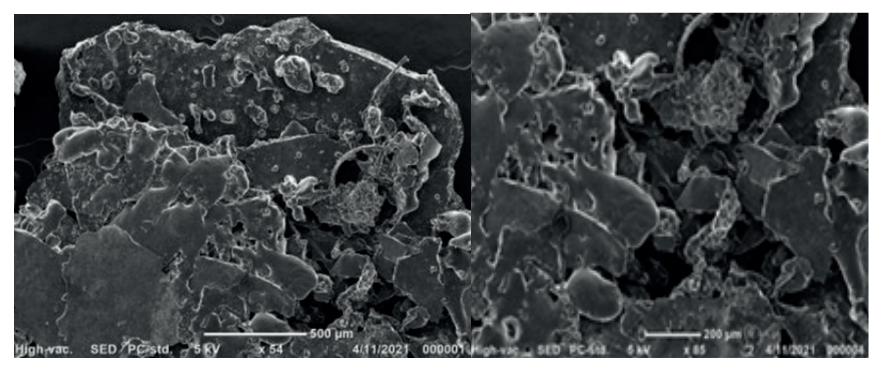

Figure .3 SEM ANALYSIS OF COLACASSIA LEAF OF 2mM

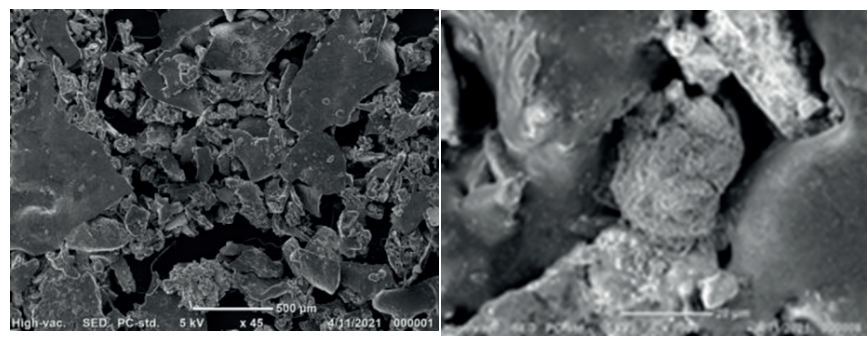

Figure .4 SEM ANALYSIS OF ABUTILON LEAF OF 4Mm

\section{EDX ANALYSIS}

The samples which were subjected to UV-Vis and SEM analysis was later followed by EDX analysis.(Figure. 5 \& 6 )

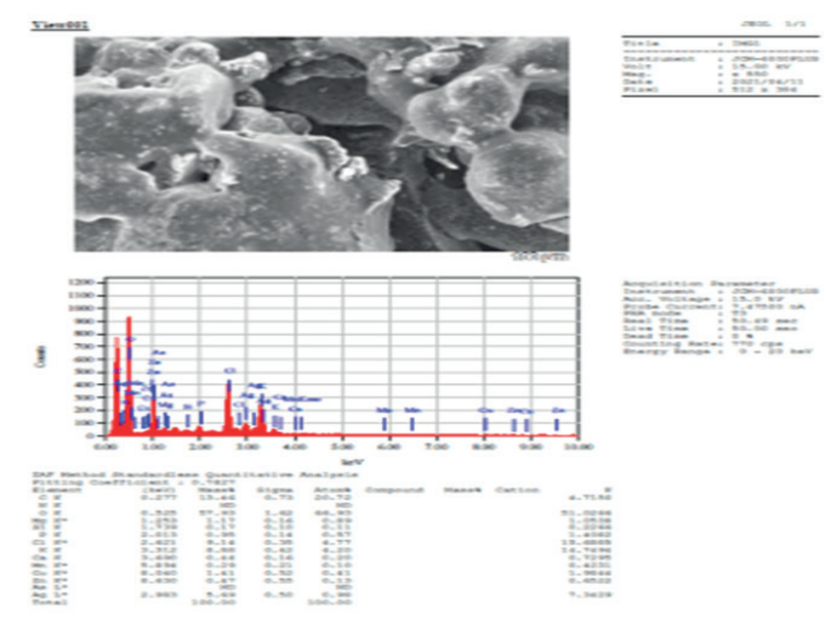

Figure.5 EDX ANALYSIS OF Colacassia leaf of $2 \mathrm{mM}$
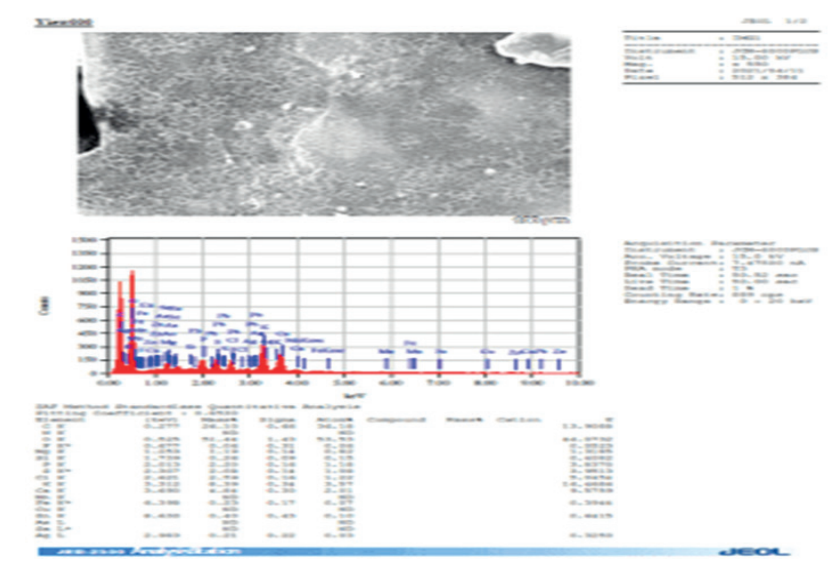

$=$

Figure.6 EDX ANALYSIS OF Abutilon leaf of $4 \mathrm{Mm}$

\section{Discussion}

From the obtained result of phytochemicals, we found out that the aqueous extract showed the presence of all phytochemicals for all the three plant samples, whereas aqueous extract of leaf of all the three plant samples indicated the presence of all phytochemicals in fairly good amount .Hence water was the main component used in the preparation of silver nanoparticles, where water was used for the filtering the plant sample which were used in the preparation of silver nanoparticles in different concentrations. The colour change from pale yellow to brown colour indicated the presence of silver nanoparticles .Once the silver nanoparticles were formed ,they were immediately subjected to characterization process by UV-Vis spectrophotometer for detecting the absorption peaks and capacity at $250-700 \mathrm{~nm}$ where Abutilon leaf of $4 \mathrm{mM}$ and Colacassia leaf of $2 \mathrm{Mm}$ were revealed to be of having high absorption capacity ,they showed maximum absorption peak at 412.83 and $420 \mathrm{~nm}$. The silver nanoparticle solution were transferred to crucible inorder to dry and make synthesised silver nanoparticles to be available in powdered form for further analysis like SEM and EDX analysis.

\section{Conclusion}

In this work we selected the plant samples with various medicinal properties for our study. We collected three plant samples namely: Colacassia esculetta, Abutilon indicum and Muntigia calabura from different regions of Bengaluru. The plant samples were separated into stem, leaves, flowers and fruits. All the plant samples were shade dried and extracted using soxhlation with three different solvents namely ethanol, methanol and water .The extracted samples were subjected to evaporation at $45^{*} \mathrm{C}$ further the extracts were screened for the phytochemicals present in them .We found out phytochemicals are well present in the aqueous extract of all the three plant leaf sample .Later we biologically synthesised silver nanoparticles by filtering dried and powdered plant sample with the double distilled water through Whattman fiter paper followed by the preparation of $\mathrm{AgNO}_{3}$ solution in different concentrations with fitered plant samples. The colour change from pale yellow to brown was observed and noted down periodically .All the synthesised silver nanoparticle solution were subjected to UV-Vis spectrophometer 